\title{
Efficacy of use of tramadol in analgesia of prepubertal queens submitted to ovaryhysterectomy
}

\author{
Camila Neves Martins ${ }^{1 *}$, Giovane Debs Guesine ${ }^{1}$, \\ Fernando Dedding Martins ${ }^{1}$, Francisco Claudio Dantas Mota ${ }^{1}$, \\ Aracelle Elisane Alves ${ }^{{ }^{*}}$
}

\begin{abstract}
The number of wandering animals in large urban centers is increasing, and the cat population is quite significant. Pre-pubertal sterilization promotes early reproductive failure of the animal; reduces the development of pathologies related to the reproductive tract, in addition of other advantages. However, anesthesia in prepubertal animals is still a challenge and the usage of opioids in those patient has been questioned due to the occurrence of hypotension in some cases. Accordingly, it is necessary further studies to verify the consequences of the use of opioids in these animals. Therefore, the present study had as objective to evaluate the effectiveness of the use of Tramadol in prepubescent queens submitted to ovariohisterectomy. Eight females of the feline species, aged between two and four months, were used. The queens were randomly divided into two groups (Control group and Tramadol group), consisting of four animals each. During the transoperative period, body temperature, respiratory rate, heart rate and oxygen saturation, and noninvasive blood pressure had been monitored. They have been measured immediately prior to administration of anesthetic drugs (T0 - Control) and every 4 minutes during 20 minute of transoperative period (T4, T8, T12, T16, T20); heart rate parameters; respiratory rate, body temperature, oxygen saturation level and systolic blood pressure (SBP). The Tramadol group presented lower values - of heart rate and respiratory rate when compared to those obtained in the Control group in the periods from T0 to T8. In all analyzed moments body temperature and oxygen saturation did not reveal significant difference between the two groups; with values - between $35.6^{\circ}$ $\mathrm{C}$ and $37.7^{\circ} \mathrm{C}$ and $78.5 \%$ and $90.25 \%$, respectively. In this study it was possible to conclude that Tramadol was efficient in analgesia after surgical sterilization of prepubertal cats, without causing significant hypotension.
\end{abstract}

Key words: pre pubertal, opioids, ovariohisterectomy, cats, felis catus.

$* * *$

\footnotetext{
${ }^{1}$ Hospital Veterinário da Faculdade de Medicina Veterinária da Universidade Federal de Uberlândia. * Corresponding author: Av. Pará, 1720 - Bloco 2T, Bairro Umuarama, Uberlândia MG - CEP 38400902. E-mail: camilanvet@gmail.com
} 


\section{Introduction}

The number of dogs and cats has increased intensively in recent years, especially stray animals in large urban centers. Some measures should be taken to reduce the number of abandoned animals, such as: community awareness and animal sterilization projects, aiming population control. A major consequence of the large number of wandering animals is the transmission of zoonosis, which has great relevance for public health, mainly by the transmission of leishmaniosis, rabies disease, leptospirosis, toxoplasmosis, heartworm disease, among others (ALVES, 2005).

Mass sterilization campaigns have been carried out, aiming the population control of the wandering animals in order to offer greater security to the entire population. Surgical sterilization of animals is a definitive alternative, safe, and efficient method for reproductive control (DE LACERDA et al, 2010; MACEDO, 2011). This practice also reduces the incidence of hormone-dependent tumors, as well as pathologies that affect the organs related to reproduction. In addition, sterilized animals can be more easily adopted, which contributes even more to this population control (ALVES, 2005). However, there is controversy over the ideal age at which sterilization can be performed because of the physiological and anatomical differences that exist between young and adult animals. The physiological differences are present in the respiratory, cardiovascular, hepatorenal, metabolic and thermoregulatory systems between puppies and adults of dogs and cats (ALEIXO et al, 2017).

A possible relation of sterilization in prepubertal animals has been reported and includes urinary incontinence, obesity and exaggerated growth due to delayed closure of the bony epiphyses, among others (MACEDO, 2011). However, sterilization of prepubertal females has the following advantages: mammary tumor prevention, pyometra treatment, uterine and ovarian tumors, metritis, ovarian cysts, vaginal prolapse, uterine torsion, 
and vaginal hyperplasia among others (FOSSUM, 2015). In addition, castration before the first estrus ensures infertility, and is very relevant mainly in wandering cats since they are pluriparas and seasonal poliestric (JOHNSTON et al, 2001).

The choice of analgesia and anesthesia to be applied to these animals should be cautious. Opioids produce good analgesia; however, they produce sedation and/or excitation, respiratory depression and reduced gastrointestinal motility, and may also promote changes in body temperature (HALL \& CLARK, 1991). In puppies, the use of opioids can cause sinus bradycardia and respiratory depression (LICHTERLER, 2014). Therefore, the recommended dose of opioids for these patients is reduced to $50 \%$ of the adult dose (GRAND \& DUNLOP, 1991).

Despite those facts; the benefits offered by sterilization at this age are still greater than the disadvantages, and therefore the need for studies evaluating new anesthetic protocols that offer better well being to the animals sterilized early. Therefore, the objective of this study was to evaluate two anesthetic protocols during the transoperatory period of prepubertal queens submitted to ovariohisterectomy.

\section{Material and methods}

It has been used 8 female cats, without breed choice, considered healthy after clinical and laboratorial exams, weight between 1 and $1.8 \mathrm{~kg}$ and age between 2 and 4 months old. This study has been developed after ethical committer approval and all the animals were included with owner's authorization. The females were submitted to 6 hours food and water fasting and allocated randomly in two groups (control and Tramadol) with 4 animals each group.

The animals from the control group received as preanesthetic, induction and maintenance medication the association of $0.05 \mathrm{mg} / \mathrm{kg}$ of 
acepromazine and $10 \mathrm{mg} / \mathrm{kg}$ of tiletamine/zolazepam. The animals from the group Tramadol received the same protocol, in addiction of $2 \mathrm{mg} / \mathrm{kg}$ de Tramadol. For booth groups, all the drugs were allocated at the same syringe and administrated by intramuscular route.

After check that the animals were in anesthetic plane, the animals were positioned in dorsal recumbency, trichotomy and asepsis were performed as usual. Then, all the animals were submitted to ovariohisterectomy using the technique described by Fossum (2015).

The following parameters: heart rate (FC); respiratory rate (FR), body temperature (TC), oxigen saturation level (SPO2) and systolic arterial pressure (PAS) were checked imediately before the drugs administrations (Time 0 or T0) and after every 4 minutes during the 20 minutes of surgery, being after 4 minutes (T4), 8 minutes (T8), 12 minutes (T12), 16 minutes (T16) and 20 minutes (T20). The evaluations were performed by a multiparametric monitor (model Bioease- bio pact 6 vet) who provided, by a clamp on the animal's tongue, the parameters FC and SPO2 and by the oscillometric method provided PAS. The FR (respiratory frequency) was evaluated by observing thoracic movements and breaths per minute. The data was submitted to statistical analysis by the program SAS, using the ANOVA and Tukey tests. Significance was set for $p>0,05$.

\section{Results and discussion}

According to Biebuyck (1990), the incorrect treatment of pain might produce negative effects on the cardiovascular, respiratory, gastric, neuroendocrine and immune systems.

The heart rate on the animals from the control group reveal average of $206.5 \mathrm{bpm}$ at T0; $234.25 \mathrm{bpm}$ at T4; $239.75 \mathrm{bpm}$ at T8; $195.75 \mathrm{bpm}$ at T12; $189.5 \mathrm{bpm}$ at T16 e $183.5 \mathrm{bpm}$ at T20, while the group Tramadol had an 
average of $203.75 \mathrm{bpm}$ at T0; $211 \mathrm{bpm}$ at T4; $214.25 \mathrm{bpm}$ at T8; $216.5 \mathrm{bpm}$ at T12; $201.75 \mathrm{bpm}$ at T16 and finally $197.75 \mathrm{bpm}$ at T 20 .

Only $\mathrm{T} 4$ and $\mathrm{T} 8$ have shown statistical significance between the Tramadol and Control groups, being the heart rate of the control group higher at those two evaluations. During the other evaluations, the difference among values were minimal, not being considered statistically significant. Those data are shown at figure 01.

The respiratory rate during the transoperative presented on the control group was at T0: $35 \mathrm{mpm} ; 31 \mathrm{mpm}$ at T4; $35 \mathrm{mpm}$ at T8; $28 \mathrm{mpm}$ at $\mathrm{T} 12 ; 26.5 \mathrm{mpm}$ at T16 and $33 \mathrm{mpm}$ at T20. The group Tramadol presented at T0 the rate of $26 \mathrm{mpm} ; 21.5 \mathrm{mpm}$ at $\mathrm{T} 4 ; 24.25 \mathrm{mpm}$ at $\mathrm{T} 8 ; 24.5 \mathrm{mpm}$ at $\mathrm{T} 12$; $23.5 \mathrm{mpm}$ at T16 and $29.5 \mathrm{mpm}$ at T20. Only T0 and T8 have shown statistical significance between the Tramadol and Control groups, being the rates of the Tramadol group lower at those two evaluations. The respiratory rate data is presented at figure 02 .

Likewise the striking feature of the opioids, Tramadol causes respiratory depression, but it is still smaller than the caused by morphine, according to a study made by Mastrocinque and Fantoni (2003), who evaluated the use of these two drugs on the postoperative of bitches undergoing ovariohisterectomy, and verified the advantages offered by Tramadol overlaps its negative effects. It is also important to emphasize that pain causes tachypnea in cats (Beata et al., 2007), reaffirming the analgesic effect of Tramadol, since it caused inferior FR on animals who received this drug.

It is also important to emphasize that the surgical time T4 and T8 corresponds to the surgical access of abdominal cavity and localization of ovarian pedicle, circumstances that causes higher pain stimulation, meaning grater analgesia on animals receiving Tramadol.

According to De Monte et al., (2017) and Saliba et al., (2011), in the presence of pain, there is an increase of oxygen consumption by the 
myocard, increasing the heart work; what can be demonstrated by the heart rate increase. Therefore, it was possible to observe that Tramadol offered greater analgesia, justifying a lower heart rate at this group.

Nowadays, Tramadol is one of the most used opioids in the veterinary medicine designed to pain treatment in dogs. This drug has been revealed advantages over the traditional opioids due to a small incidence of adverse effects (SHIPTON 2000), and longer effects if compared to more powerful opioids like morphine (MARTINS ET AL. 2010; VETTORATO ET AL. 2010). Despite these advantages, there are few reports in the veterinary medicine about the efficiency of Tramadol during postoperative pain control in dogs. In a previous study, Tramadol has provided decent analgesia for bitches undergoing ovariohisterectomy according to Mastroncinque \& Fantoni (2003).

The temperature at the Tramadol group was $37.7^{\circ} \mathrm{C}$ at $\mathrm{T} 0 ; 37.5^{\circ} \mathrm{C}$ at T4; $37.4{ }^{\circ} \mathrm{C}$ at $\mathrm{T} 8 ; 36.8{ }^{\circ} \mathrm{C}$ at $\mathrm{T} 12 ; 36.7{ }^{\circ} \mathrm{C}$ at $\mathrm{T} 16$ and $36,6{ }^{\circ} \mathrm{C}$ at $\mathrm{T} 20$, meanwhile the control group presented $37.5{ }^{\circ} \mathrm{C}$ at T0; $37 ., 3{ }^{\circ} \mathrm{C}$ at $\mathrm{T} 4 ; 36.9{ }^{\circ} \mathrm{C}$ at $\mathrm{T} 8 ; 36.5^{\circ} \mathrm{C}$ at $\mathrm{T} 12 ; 36.3{ }^{\circ} \mathrm{C}$ at $\mathrm{T} 16$ and $36.1{ }^{\circ} \mathrm{C}$ at T20 (picture 03 ). There was no significant difference on postoperative temperature among the evaluations done. Therefore, we can conclude that in the present study, Tramadol has not caused hypothermia in pre pubertal dogs, as mentioned previously by Zago (2013), that has demonstrated that opioids might cause hypothermia in puppies. According to Soares et al., (2015) small size animals have a better chance to show hypothermia after surgery due to smaller corporal area to heat exchange. However, this is more common after long time surgeries, and since the average surgical time was 20 minutes, it is justified no statistical difference between the two groups.

It was possible to verify on this study the SPO2 rates at Tramadol group showed from 88,25 to $90,25 \%$, at control group the range was from $78,5 \%$ to $95,25 \%$ for every time. Therefore, there has been no significant difference between the groups, which means that Tramadol has not caused 
bradycardia, so the oxygenation showed stable, not causing SPO2 alterations (Figure 4).

According to Beata et al., (2007) cats might show many sudden signals related to the state of anxiety and stress such as tachycardia, mydriasis, tachypnea, increase of strength and muscular contractions, vocalization, changes on corporal and facial expressions and also alterations of arterial pressure rates. The pain causes increase on liquid retention and activation of renin-angiotensin system, which lead to higher arterial pressure and decreases renal perfusion (LESTER; GAYNOR, 2000).

Following the same condition, similar heart rate alteration has been observed on the arterial pressure data at the present study. Due to this dependence from the heart rate, the arterial pressure creates during the cardiac cycle (set of events between one beat and the next beat) a peak vascular distension wave. This wave shows during the heart contraction (systole) a peak (arterial systolic pressure - PAS) of 110 to $160 \mathrm{mmHg}$ in dogs and $160 \mathrm{mmHg}$ in cats and during the cardiac relaxation (diastole) a minimal peak (diastolic arterial pressure - PAD) of 70 to $90 \mathrm{mmHg}$ in dogs and cats, values that match the ones found by Anjos et al., (2014) and the present study.

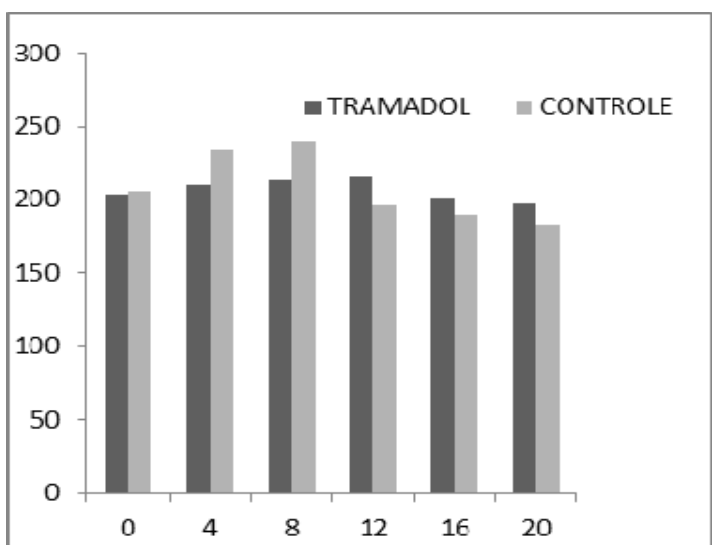

Figure 01: Graphic representation of average heart rates (bpm) during transoperative of pre pubertal female cats undergoing ovariohisterectomy.

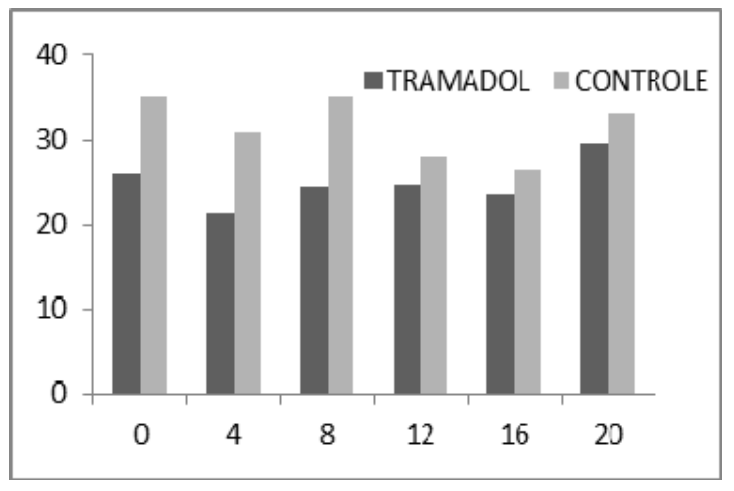

Figure 02: Graphic representation of average respiratory rates (bpm) during transoperative of pre pubertal female cats undergoing ovariohisterectomy. 


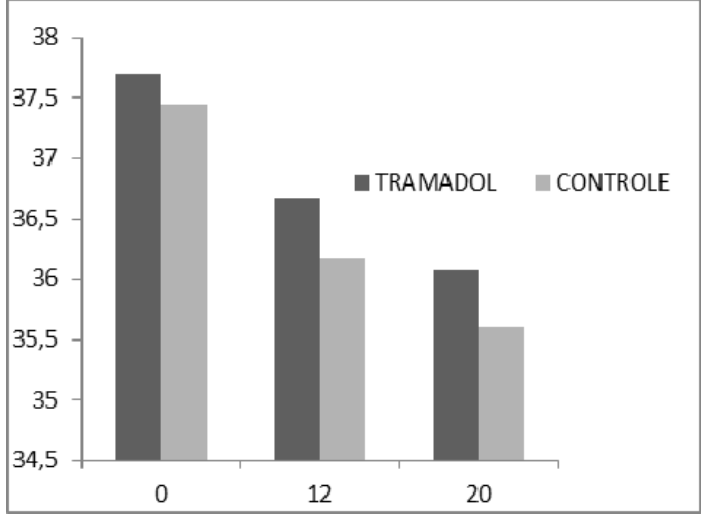

Figure 03: Graphic representation of average of rectal temperature rates $\left({ }^{\circ} \mathrm{C}\right)$ during transoperative of pre pubertal female cats undergoing ovariohisterectomy.

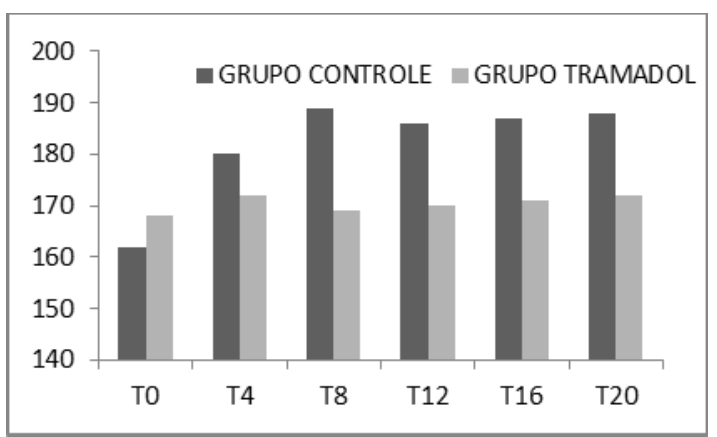

Figure 05: Graphic representation of average arterial pressure rates $(\mathrm{mmHg})$ during transoperative of pre pubertal female cats undergoing ovariohisterectomy.

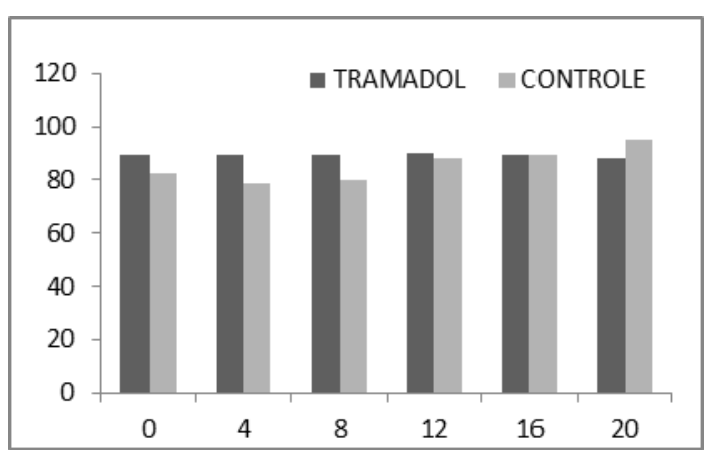

Figure 04: Graphic representation of average oxygen saturation (\%) during transoperative of pre pubertal female cats undergoing ovariohisterectomy.

\section{Conclusion}

At the present study, the animals that received Tramadol revealed inferior values of heart rate and respiratory rate during the transoperative period. However, the other parameters (SPO2 and rectal temperature) did not show statistical difference between the Tramadol and Control group. Therefore, we can conclude according to superior advantages on the majority of analyzed parameters that Tramadol can be used in the anesthesia of pre pubertal cats, offering analgesia and welfare for the animals during the transoperative. 


\title{
Eficácia do uso de tramadol na analgesia de gatas pré púberes submetidas à ovariohisterectomia
}

\begin{abstract}
Resumo: É crescente o número de animais errantes nos grandes centros urbanos, sendo a população de felinos bastante significativa. A esterilização pré púbere promove de forma precoce a incapacidade reprodutiva do animal; reduz o desenvolvimento de patologias relacionadas ao trato reprodutivo, além de outras vantagens. Entretanto a anestesia em animais pré púberes ainda é um desafio e o uso de opióides nestes pacientes tem sido questionado devido a ocorrência de hipotensão em alguns casos. Sendo assim tornam-se necessários estudos para verificar as consequências do uso de opióides nestes animais. Portanto, o presente estudo teve como objetivo avaliar a eficiência do uso de Tramadol em gatas pré-púberes submetidas à ovariosalpingohisterectomia. Foram utilizadas oito fêmeas da espécie felina, com idade entre dois e quatro meses. As gatas foram divididas aleatoriamente em dois grupos (grupo Controle e grupo Tramadol), constituídos de 4 animais cada. Durante o trans operatório foram avaliadas a temperatura corporal, frequência respiratória, frequência cardíaca e saturação de oxigênio e pressão arterial não invasiva. Foram aferidos imediatamente antes da administração das drogas anestésicas (T0 - Controle) e a cada 4 minutos durante o transoperatório de 20 minutos (T4, T8, T12,T16, T20); os parâmetros de frequência cardíaca; frequência respiratória, temperatura corporal, nível de saturação de oxigênio e pressão arterial sistólica (PAS). O grupo Tramadol apresentou valores de frequência cardíaca e respiratória inferiores quando comparados com os obtidos no grupo Controle nos períodos de T0 até o T8. Em todos os momentos analisados a temperatura corporal e saturação de oxigênio não revelaram diferença significativa entre os dois grupos; sendo que os valores se mantiveram entre $35,6^{\circ} \mathrm{C}$ a $37,7^{\circ} \mathrm{C}$ e $78,5 \%$ a $90,25 \%$ respectivamente. Neste estudo foi possível concluir que o Tramadol foi eficiente na analgesia após esterilização cirúrgica de gatas pré púberes, sem causar hipotensão significativa.

Palavra-chave: opióide, esterilização, felinos, felis catus.
\end{abstract}

\section{References}

ALEIXO, G. A. S. et al. Tratamento da dor em pequenos animais: fisiopatologia e reconhecimento da dor (revisão de literatura: parte I). Medicina Veterinária (UFRPE), v. 10, n. 1-4, p. 19-24, 2017.

ALVES, A. E. Avaliação dos parâmetros comportamentais, fisiológicos e laboratoriais de fêmeas felinas submetidas à ovarioectomia por videolaparoscopia e abordagem convencional. Tese de mestrado. Universidade Estadual Paulista. 2005. 
ANJOS, T. M. et al. Avaliação e comparação entre métodos de mensuração de pressão arterial sistólica em gatos hígidos anestesiados. Arquivo Brasileiro de Medicina Veterinária e Zootecnia, v. 66, n. 4, p. 1051-1059, 2014. https://doi.org/10.1590/1678-6722

BEATA, C. et al. Effect of alpha-casozepine (Zylkene) on anxiety in cats. Journal of Veterinary Behavior: Clinical Applications and Research, v. 2, n. 2, p. 4046, 2007. https://doi.org/10.1016/j.jveb.2007.02.002

BIEBUYCK, J. F.; PHIL, D. The metabolic response to stress: an overview and update. Anesthesiology, v. 73, n. 4, p. 308-327, 1990.

BROWN, S. et al. Guidelines for the identification, evaluation, and management of systemic hypertension in dogs and cats. Journal of veterinary internal medicine, v. 21, n. 3, p. 542-558, 2007.

https://doi.org/10.1111/j.1939-1676.2007.tb03005.x

BIAZZOTO, C, B. et al. Hipotermia no período perioperatório. Revista Brasileira de Anestesiologia, v. 56, n. 1, p. 56-66, 2006.

DAYER, P.; DESMEULES, J.; COLLART, L. Pharmacologie du tramadol. Drugs, v. 53, n. 2, p. 18-24, 1997. https://doi.org/10.2165/00003495-199700532-00006

DE MONTE, V. et al. Heart rate and blood pressure variations after transvascular patent ductus arteriosus occlusion in dogs. Research in Veterinary Science, v. 113, p. 73-78, 2017. https://doi.org/10.1016/j.rvsc.2017.09.004

DEWEY, C. W. et al. Evalution of an Epidural Intracranial Pressure Monitoring System in Cats. Journal of Veterinary Emergency and Critical Care, v. 7, n. 1, p. 20-33, 1997. https://doi.org/10.1111/j.1476-4431.1997.tb00041.x

FAGGELLA, A. M.; ARONSOHN, M. G. Evaluation of anesthetic protocols for neutering 6-to 14-week-old pups. Journal of the American Veterinary Medical Association, v. 205, n. 2, p. 308-314, 1994. 
FOssum, T. W. Cirurgia de Pequenos Animais. 4. ed. Rio de Janeiro: Mosby Elsevier, cap. XXVII. p. 789. 2015.

GUINSBURG, R. et al. Physiological, hormonal, and behavioral responses to a single fentanyl dose in intubated and ventilated preterm neonates. The Journal of pediatrics, v. 132, n. 6, p. 954-959, 1998.

GRANDY, J. L.; DUNLOP, C. I. Anesthesia of puppies and kittens. Journal of American Veterinary Medical Association, v. 198, n. 7, p. 1244-1249, 1991.

HALL, L. W. \& CLARK, K. W. Anesthesia for Obstetrics. Veterinary Anesthesia, n. 9, p. 360-362. 1991.

HELLYER, P. W.; GAYNOR, J, S. Acute postsurgical pain in dog and cats. Compendium on continuing education for the practicing veterinarian small animal, v. 20, n. 2, p. 140-153, 1998.

HUGONNARD, M. et al. Attitudes and concerns of French veterinarians towards pain and analgesia in dogs and cats. Veterinary anaesthesia and analgesia, v. 31, n. 3, p. 154-163, 2004.

JOHNSTON, S. D.; ROOT-KUSTRITZ, M. V.; OLSON, P. N. The feline estrous cycle. Canine and Feline Theriogenology, p. 396-405, 2001.

DE LACERDA, M. S.; SAMPAIO, R. L.; NUNES, T. C. Estudo hematológico e cardiorrespiratório em cadelas anestesiadas com cetamina-s/xilazina e tiletamina/zolazepam e submetidas a ovário-histerectomia. Bioscience Journal, v. 26, n. $6,2010$.

LESTER, P.; GAYNOR, J. S. Management of cancer pain. Veterinary Clinics: Small Animal Practice, v. 30, n. 4, p. 951-966, 2000. 
LICHTLER, J. Castração precoce em pequenos animais: Técnicas, vantagens, riscos e uso no controle populacional. Monografia, UFRS, Porto Alegre; 2014.

LIVINGSTON, A. Physiological basis for pain perception in animals. Veterinary Anaesthesia and Analgesia, v. 21, n. 2, p. 73-77, 1994.

MACEDO, J. B. Castração precoce em pequenos animais: prós e contras. TCC (Pós Graduação em Clínica Medica e Cirúrgica de Pequenos Animais, da Universidade Castelo Branco). Goiânia, 2011.

MARTINS, T. L. et al. Comparison of the effects of tramadol, codeine, and ketoprofen alone or in combination on postoperative pain and on concentrations of blood glucose, serum cortisol, and serum interleukin-6 in dogs undergoing maxillectomy or mandibulectomy. American journal of veterinary research, $\mathrm{v}$. 71, n. 9, p. 1019-1026, 2010. https://doi.org/10.2460/ajvr.71.9.1019

MASTROCINQUE, S.; FANTONI, D. T. A comparison of preoperative tramadol and morphine for the control of early postoperative pain in canine ovariohysterectomy. Veterinary anaesthesia and analgesia, v. 30, n. 4, p. 220228, 2003. https://doi.org/10.1046/j.1467-2995.2003.00090.x

MATTOS, A. H. Avaliação da pressão arterial pela mensuração com Doppler vascular e retinografia de cães hipertensos. 2012. xii, 71 f., il. Dissertação (Mestrado em Saúde Animal) - Universidade de Brasília, Brasília, 2012.

MERKEL, S.; MALVIYA, S. Pediatric pain, tools and assessment. Journal of PeriAnesthesia Nursing, v. 15, n. 6, p. 408-414, 2000.

https://doi.org/10.1053/jpan.2000.19504

ROBERTSON, S. A.; TAYLOR, P. M. Pain management in cats-past, present and future. Part 2. Treatment of pain-clinical pharmacology. Journal of Feline Medicine \& Surgery, v. 6, n. 5, p. 321-333, 2004.

https://doi.org/10.1016/j.jfms.2003.10.002 
SALIBA, R.; HUBER, R.; PENTER, J. D. Pain control in small animals. Semina: Ciências Agrárias, v. 32, n. 4, Sup. 1, p. 1981-1988, 2011.

SOARES, G. C.; CARDOSO, C. G.; JUNIOR, E. M. Causas e consequências da hipotermia: a importância da monitoração da temperatura no perioperatório. Investigação, v. 14, n. 6, 2015.

SCOTT, L. J.; PERRY, C. M. Tramadol: a review of its use in perioperative pain. Drugs, v. 60, p.139- 176. 2000. https://doi.org/10.2165/00003495-200060010-00008

SHIPTON, E. A. Tramadol: present and future. Anaesthesia and intensive care, v. 28, n. 4 , p. $363,2000$.

SLINGSBY et al. Post operative pain after ovariohysterectomy in the cat: a comparision of two anaesthetic regimens. Veterinarian Record, p. 589, 1998.

SLINGSBY, L. S.; WATERMAN-PEARSON, A. E. Comparasion of pethidine, buprenorphine and ketoprofen for postoperative analgesic after ovariohysterectomy in the cat. Veterinary Pec, v. 143, p. 185, 1998.

TEIXEIRA, R. C. R et al. Effects of tramadol alone, in combination with meloxicam or dipyrone, on postoperative pain and the analgesic requirement in dogs undergoing unilateral mastectomy with or without ovariohysterectomy. Veterinary anaesthesia and analgesia, v. 40, n. 6, p. 641-649, 2013.

https://doi.org/10.1111/vaa.12080

WRIGHT,A. Neurophysiology of pain and pain modulation in strong pain. Textbook for Therapist, p. 43-64, 2002.

ZAGO, B. S. Prós e contras da castração precoce em pequenos animais. TCC (Universidade Federal do Rio Grande do Sul). Rio Grande do Sul, 2013. 